\title{
The use of the high-resolution LiDAR DTM by the Italian Ministry of the Environment and for Protection of the Land and Sea in archeology
}

\author{
Micaela Leonardi ${ }^{\mathrm{a}}$, Paola Guerreschi ${ }^{\mathrm{b}}$ * \\ ${ }^{a}$ Department of History, Archeology and Art History, Università Cattolica del Sacro Cuore Milano - micaela.leonardi@unicatt.it \\ $b$ Interuniversity Department of Regional and Urban Studies and Planning, Politecnico and University of Turin - \\ paola.guerreschi@unito.it \\ * Corresponding author
}

Keywords: DTM, Archeology, LiDAR

\section{Abstract:}

The increase of the cartographic open data availability, as well as the simplified use of the GIS processing application, allowed the archaeologists to analyse the data - acquired with traditional methods - in a single georeferenced ambient; from the historical maps, to the present digital land surveys (DTM). This process increased, by far, the data availability for the ancient time landscape reconstruction.

The surprising results of the use of DTMs, made with LiDAR technology in the archaeological field, are known. Thanks to their potentials, they can provide a detailed landscape survey whenever covered by vegetation, revealing underground artefacts in case they have been preserved elevation evidence; positive or negative (Opitz and Crowley, 2013). Their capabilities have emerged in marginal areas, where the human intervention has been zero or minimal in the modern age: exceptional results have been obtained, for example, in the Cambodian jungle and in Mesoamerica, as well as in the European uncultivated areas, too $^{1}$.

The digital landscape Model (DTM), based on LiDAR technology and made by the Italian Ministry of the Environment and for Protection of the Land and Sea - as part of the Extraordinary Environmental Remote Sensing Plan (PST-A extension 2008) ${ }^{2}$ includes the more instable areas of the whole Italian landscape, only. Actually, it was created to monitor the hydrogeological high-risk areas, predicting and managing the consequences of natural events. Nevertheless, it represents an excellent tool, giving the high resolution (1-meter step) to be used in archaeological studies.
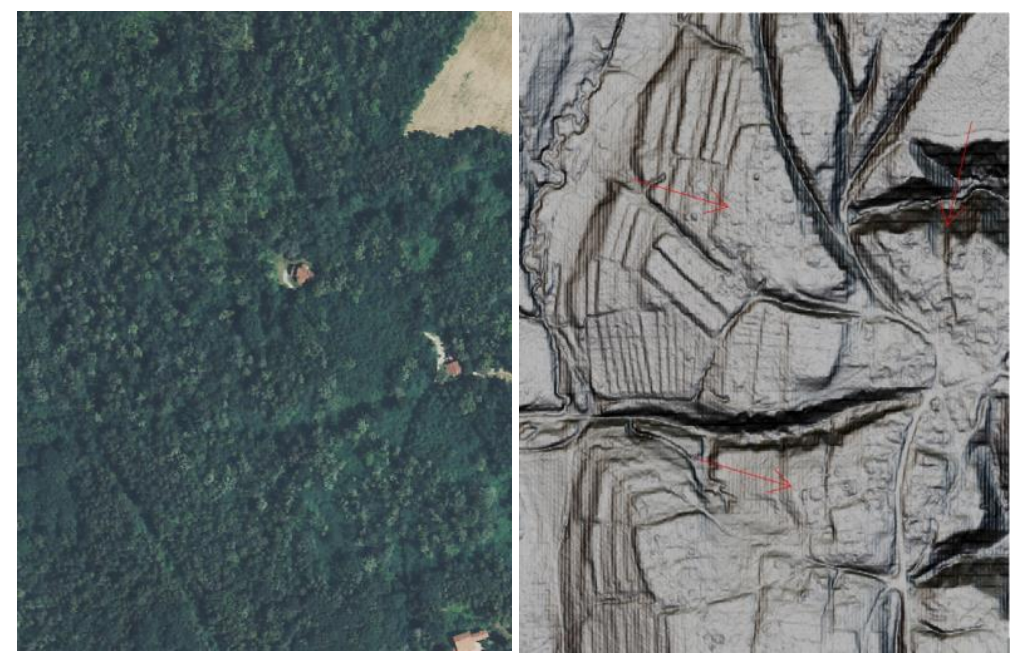

Figure 1. Unesco site of Castelseprio (Olona, VA) ${ }^{3}$. National cartographic geoportal, Color orthophoto 2006; On the right side: elaboration of the DTM as multiple Hillshade (D16-H10) on Slope visualisation

It clearly highlighted that in Italy the uncultivated land extension is minimal, and the massive changings applied to the lowland areas by the mechanized agricultural, cancelled the micro morphologies. It is quite rare to identify underground artifacts, signs of agricultural subdivisions and road tracing, even if they emerge as crop marks or single marks that can be found in the aerial view.

\footnotetext{
${ }^{1}$ In the region of Carso Montains, near Trieste, in a complex archaeological landscape, the MATTM DTM allowed the identification of fortified unknown structures dated from prehistory to the Roman times (Bernardini et al., 2013).

${ }^{2}$ http://www.pcn.minambiente.it/mattm/progetto-piano-straordinario-di-telerilevamento/
} 
However, there was not lack of surprising results, allowing the recognition of significant buried archaeological ruins in marginal areas and rebuilding their plan with extraordinary accuracy. For example, it happened in Castelseprio Lombardy ${ }^{4}$ - for the early medieval buildings belonging to the village built nearby Santa Maria Church foris portas, outside the famous castrum. Due to those important achievements, punctual ground controls were planned, confirming presences in the bush, by remote recognition (Giostra and Leonardi, 2017) . $^{5}$

In Pinerolo, a Piedmonts' fortified city with complex modern defences between the sixteenth and seventeenth centuries, with interventions undertaken both by the Savoy and, in the course of two distinct occupations, by the French, the use of the DTM has shown the persistence of elements attributable to the foundation cuts practiced in the rock, or to the negative left by the complete and systematic removal of the curtains. These altimetric evidences, hardly or at all perceptible from the ground, constitute the only persistence of notable artifacts that should be protected. There have been occasions in which the DTM has instead, on the contrary, denounced the partial or complete removal resulting from senseless leveling ${ }^{6}$.

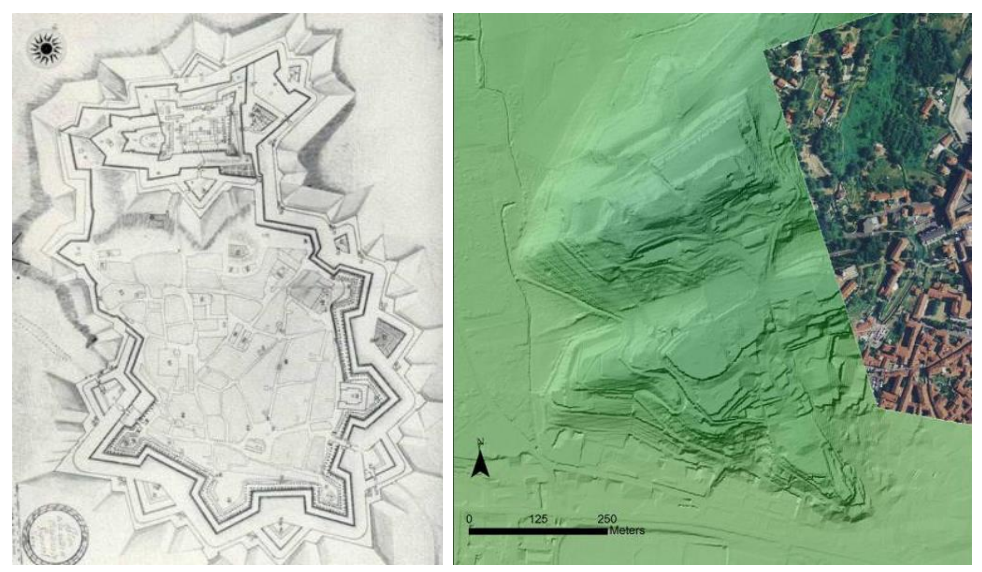

Figure 2. Pinerolo in 1679, Municipal Archive; to the right the DTM visualization of hillshade

In lowland contexts, where these phenomena are more evident, valuable information have been found mainly in relation to the paleo hydrographic network.

It should be underlined that today the combination of coaching and integrating the information got by the application of photogrammetric techniques to drone shots, is heavily used in archaeological research. Information that can lead to centimetre resolution products for limited territorial extensions.

However, their use is still limited to single excavation contexts, while their use on a larger scale still presents few case studies, only.

\section{References}

Bernardini, F., Sgambati, A., Montagnari Kokelj, M., Zaccaria, C., Micheli R., Fragiacomo, A., Tiussi, C., Dreossi, D., Tuniz, C. and De Mina, A., 2013. Airborne LiDAR application to Karstic Areas: the example of Trieste province (northeastern Italy) from prehistoric sites to Roman forts. In: Journal of Archaeological Science, 40, pp. 2152-2160.

Chase, A.F., Chase, D.Z., Weishampel, J.F., Drake, J.B., Shrestha, R.L., Slatton, K.C., Awef, J.J. and Carter, W.E., 2011. Airborne LiDAR, archaeology, and the ancient Maya landscape at Caracol, Belize. In: Journal of Archaeological Science, 38, pp. 387-398.

Giostra, C. and Leonardi, M., 2017. Il borgo: analisi diagnostiche preliminari in 1287 e dintorni. Ricerche su Castelseprio a 730 anni dalla distruzione. In: Atti della Giornata di studi S.A.P. Società Archeologica - Mantova, November 27, 2017, Milan, Italy, pp. 275-294

Leonardi, M., 2019. Cost distance e viewshed analysis per un modello ricostruttivo dei percorsi in Alta Val Tanaro. In: Demeglio, P. (ed.), Un paesaggio medievale tra Piemonte e Liguria: il sito di Santa Giulitta e l'Alta Val Tanaro, Sesto Fiorentino (FI), All'Insegna del Giglio, pp. 71-85.

Opitz, R.S. and Crowley, D.C., 2013. Interpreting archaeological topography. Airbone laser scanning 3D data and ground observation, Oxford, England, Oxbow Books.

\footnotetext{
${ }^{4} \mathrm{http} / / /$ archeologiamedievale.unisi.it/castelseprio/larea-archeologica/il-castrum

${ }^{5}$ In 2020 the investigation was extended to the Castrum area too, alongside geophysical analysis (Castelseprio invisible project: diagnostic research to enhance knowledge, integration and use of archaeological areas of Castelseprio and Torba). In this case was used the 0,5 meters resolution DTM - year 2015 model, made by the Province of Varese.

${ }^{6}$ The data acquired via DTM are under investigation and analyzed together with to the rich cartography documentation preserved in the Pinerolo archive, as well at the Bibliothèque Nationale de France - Digital library.
} 